\title{
TINJAUAN YURIDIS PENGAJUAN PEMBATALAN \\ PERJANJIAN JUAL BELI SAHAM PERUSAHAAN \\ SECARA SEPIHAK
}

\author{
Satriyo Wahyu Harsoyo \\ PT Pupuk Kalimantan Timur \\ J1. James Simandjuntak No. 1 Bontang \\ Email: satriyo.wahyu@pupukkaltim.com
}

\begin{abstract}
Contract is an act by which one or more persons bind themselves to one person or more. Contract thus legally binding on the parties, to obtain rights or obligations specified in the contract. However, in a contract, not always run smoothly. As happened in filing a Share Purchase contract cancellation PT Kaltim Satria Samudera (PT KSS) between the Sellers the Yayasan Kesejahteraan Hari Tua(YKHT) with buyers Yayasan Pupuk Kaltim(YPK). Stock purchase plan agreement signed by PT KSS YPK and YKHT not include cancellation terms of the contract. The absence of a condition in the contract void makes negotiating the cancellation of the sale and purchase of shares in PT KSS be deadlock. This paper based on normative legal research. The results obtained indicate that based on the Theory of Legal System, the parties can resolve this disputeby means of negotiation and mediation. Retrieved alsoconcluded that the submission of cancellation of the contract can be done with the agreement of the parties or the cancellation of the contrac tto the court.
\end{abstract}

Key words: contract, canceled, shares

\begin{abstract}
Abstrak
Perjanjian adalah suatu perbuatan dengan mana satu orang atau lebih mengikatkan dirinya terhadap satu orang atau lebih. Perjanjian dengan demikian mengikat para pihak secara hukum, untuk mendapatkan hak atau melaksanakan kewajiban yang ditentukan dalam perjanjian itu. Namun dalam suatu perjanjian, tidak selamanya dapat berjalan dengan lancar. Seperti yang terjadi dalam Pengajuan pembatalan Perjanjian Jual Beli Saham PT Kaltim Satria Samudra (PT KSS) antara Pihak Penjual yaitu Yayasan Kesejahteraan Hari Tua (YKHT) dengan pembeli Yayasan Pupuk Kaltim (YPK). Kesepakatan rencana pembelian saham PT KSS yang ditandatangi oleh YPK dan YKHT tidak mencantumkan syarat pembatalan perjanjian tersebut. Ketiadaan syarat batal dalam perjanjian tersebut membuat negosiasi pembatalan jual beli saham PT KSS menjadi deadlock. Tulisan ini berdasarkan hasil penelitian hukum normatif dengan pendekatan peraturan perundang-undangan dan pendekatan kasus. Diperoleh hasil bahwa berdasarkan tinjauan Teori Sistem Hukum, para pihak dapat menyelesaikan sengketa ini dengan cara negosiasi dan mediasi. Diperoleh juga kesimpulan bahwa cara pengajuan pembatalan perjanjian dapat dilakukan dengan kesepakatan para pihak atau pengajuan pembatalan perjanjian ke Pengadilan
\end{abstract}

Kata kunci: perjanjian, batal, saham 


\section{Latar Belakang}

Perjanjian adalah suatu peristiwa dimana seorang berjanji kepada seorang yang lain atau dimana dua orang itu saling berjanji untuk melaksanakan sesuatu hal. ${ }^{1}$ Sedangkan definisi perjanjian menurut pasal 1313 Kitab Undang-Undang Hukum Perdata (KUHPerdata), Perjanjian adalah suatu perbuatan dengan mana satu orang atau lebih mengikatkan dirinya terhadap satu orang atau lebih. Perjanjian dengan demikian mengikat para pihak secara hukum, untuk mendapatkan hak atau melaksanakan kewajiban yang ditentukan dalam perjanjian itu. ${ }^{2}$ Perjanjian memberikan kepastian bagi penyelesaian sengketa, dan perjanjian ditujukan untuk memperjelas hubungan hukum. ${ }^{3}$

Berdasarkan Pasal 1320 KUHPerdata, ada empat syarat sahnya perjanjian. Syarat pertama, sepakat mereka yang mengikatkan dirinya.Kesepakatan merupakan unsur mendasar dari sebuah perjanjian. Tidak akan ada suatu perjanjian apabila tidak ada orang yang sepakat untuk saling mengikatkan diri dalam perjanjian. Kesepakatan disini berarti adanya suatu kesadaran untuk saling mengikatkan diri dalam suatu perjanjian tanpa adanya paksaan dari pihak manapun.
Syarat kedua yaitu kecakapan untuk membuat perjanjian. Seorang oleh hukum dianggap tidak cakap untuk melakukan perjanjian jika orang tersebut belum berumur 21 tahun, kecuali jika ia telah kawin sebelum cukup 21 tahun. ${ }^{4}$ Sebaliknya setiap orang yang berumur 21 tahun ke atas, oleh hukum dianggap cakap, kecuali karena suatu hal dia ditaruh di bawah pengampuan, seperti gelap mata, dungu, sakit ingatan atau pemboros. ${ }^{5}$ Sementara itu, dalam Pasal 1330 KUHPerdata, ditentukan bahwa tidak cakap untuk membuat perjanjian adalah: Orang-orang yang belum dewasa, mereka yang ditaruh di bawah pengampuan, orang-orang perempuan dalam hal-hal yang ditetapkan oleh undang-undang; dan pada umumnya semua orang kepada siapa undang-undang telah melarang membuat perjanjian-perjanjian tertentu. $^{6}$ Ketentuan mengenai ketidakcakapan perempuan untuk membuat perjanjian tersebut tidak dipatuhi lagi karena hak perempuan dan laki-laki telah disamakan dalam hal membuat perjanjian sedangkan untuk orang-orang yang dilarang oleh perjanjian untuk membuat perjanjian tertentu sebenarnya tidak tergolong sebagai orang yang tidak cakap, tetapi hanya tidak berwenang membuat perjanjian tertentu. ${ }^{7}$

1 Subekti, Hukum Perjanjian, Intermasa, Jakarta, 2004, hlm. 1.

2 I Ketut Artadi dan I Dewa Nyoman Rai Asmara Putra, Implementasi Ketentuan-ketentuan Hukum Perjanjian ke dalam Perancangan Kontrak, Udayana University Press, Denpasar, 2010, hlm. 28.

3 Ibid.

4 Ahmadi Miru, Hukum Kontrak Perancangan Kontrak, RajaGrafindo Persada, Jakarta, 2007, hlm. 29.

5 Ibid.

6 Ibid.

7 Ibid., hlm. 29-30. 
Syarat Ketiga yaitu hal tertentu. Tidak ada perjanjian tanpa adanya suatu hal yang diatur. Hal tertentu itu bisa berupa memberikan sesuatu, berbuat sesuatu dan tidak berbuat sesuatu. Apabila perjanjian tersebut menyangkut mengenai suatu barang maka barang tersebut harus bisa terukur sehingga dapat diperjanjikan.

Syarat Keempat yaitu sebab yang halal. Suatu perjanjian tidak boleh mengatur hal yang bertentangan dengan ketentuan hukum. Apabila terdapat suatu perjanjian yang bertentangan dengan hukum maka perjanjian tersebut akan batal demi hukum.

Terjadinya suatu perjanjian secara hukum harus memenuhi unsur-unsur yang dapat dikelompokkan dalam tiga kelompok: unsur essensialia, unsur naturalia, dan unsur accidentalia. ${ }^{8}$

Unsur essensialia suatu perjanjian adalah unsur yang sangat penting dan mutlak harus dipenuhi untuk dapat dikatakan telah ada atau telah lahirnya suatu perjanjian. ${ }^{9}$ Hal ini dimaksudkan untuk memberikan kejelasan dari apa-apa sebenarnya yang mutlak harus disepakati dalam suatu perjanjian sehubungan dengan jenis aktivitas yang akan disepakati. ${ }^{10}$ Misalnya, seperti dalam perjanjian sewa-menyewa, harga sewa dalam perjanjian tersebut harus jelas. ${ }^{11}$ Begitu juga dengan hak-hak dari si penyewa untuk dapat menikmati penggunaan objek yang disewa tersebut tanpa adanya gangguan dari pihak-pihak lain selama masa perjanjian sewa menyewa. ${ }^{12}$ Unsur esensialia dari suatu perjanjian mewujudkan bentuk utuh dari suatu perjanjian, jika hal itu tidak dipenuhi, maka tuntutan terhadap pemenuhan perjanjian tidak dapat diterima. ${ }^{13}$

Unsur naturalia adalah unsur yang sudah diatur dalam undang-undang dan berlaku untuk setiap perjanjian, apabila para pihak tidak mengaturnya. ${ }^{14}$ Seringkali, dalam suatu perjanjian para pihak hanya mengatur secara sederhana, misalnya dalam perjanjian utang piutang tidak ditentukan bunga, sehingga secara naturalia berlaku besarnya bunga menurut undang-undang sebesar 6 persen setahun (Pasal 1767 KUHPerdata jo. Lembaran Negara tahun 1848 No. 22), tidak diatur menyangkut cacat tersembunyi, maka berlakulah ketentuan mengenai cacat tersembunyi sebagaimana ditentukan dalam Pasal 1504 KUHPerdata d1l. ${ }^{15}$

Unsur Accidentalia adalah unsur yang pada dasarnya menggambarkan keterbukaan dari

8 Ricardo Simanjuntak, Hukum Kontrak Teknik Perancangan Kontrak Bisnis, Kontan Publishing, Jakarta, 2011, hlm. 114.

$9 \quad$ Ibid., hlm. 114-115.

10 Ibid., hlm. 115.

11 Ibid.

12 Ibid.

13 I Ketut Artadi, Op.cit., hlm. 35.

14 Ibid.

15 Ibid., hlm. 35-36. 
suatu perjanjian dalam mewujudkan prinsip kebebasan berkontrak bagi para pihak. ${ }^{16}$ Para pihak dalam hal ini dapat memperjanjikan hal-hal yang telah disepakati bersama dan menuangkannya dalam perjanjian, walaupun hal-hal yang disepakati tersebut tidak secara tegas diatur dalam Undang-undang yang telah ada, sepanjang bentuk-bentuk kesepakatan tersebut telah memenuhi dasar dari persyaratan keabsahan suatu perjanjian berdasarkan pasal 1320 KUHPerdata. ${ }^{17}$ Dengan kata lain perikatan-perikatan yang lahir dari perjanjian antara pihak tersebutlah yang menjadi hukum di antara mereka. ${ }^{18}$ Akan tetapi, sebagai hukum yang bersifat menambah, walaupun para pihak tidak mencantumkan ketentuanketentuan yang tercantum dalam hukum perjanjian, karena secara naturalia dan essensialia ketentuan tersebut telah hadir dalam undang-undang maka ketentuanketentuan tersebut merupakan ketentuan yang bersifat melengkapi terhadap perjanjian yang disepakati tersebut, kecuali bila pihakpihak berkontrak tersebut secara tegas mengesampingkan keberlakuan Undangundang dan pengesampingan keberlakuan ketentuan dalam Undang-undang tersebut diperbolehkan secara hukum. ${ }^{19}$

Terdapat beberapa asas dalam perjanjian yang merupakan dasar-dasar filosofis dari suatu perjanjian. ${ }^{20}$ Asas-asas hukum ini bersifat sangat umum dan menjadi landasan berfikir, yaitu dasar ideologis aturan-aturan hukum ${ }^{21}$ Beberapa asas tersebut bersifat samar-samar dan hanya dengan upaya yang sangat keras dapat dipahami dan diurai secara jelas. ${ }^{22}$ Asas hukum merupakan sumber bagi sistem hukum yang memberi inspirasi mengenai nilai-nilai etis, moral, dan sosial masyarakat. ${ }^{23}$ Dengan demikian, asas hukum sebagai landasan norma menjadi alat uji bagi norma hukum yang ada, dalam arti norma hukum tersebut pada akhirnya harus dapat dikembalikan pada asas hukum yang menjiwainya. ${ }^{24}$

Di dalam hukum perjanjian terdapat beberapa asas penting, yaitu asas kebebasan berkontrak, asas konsensualisme dan asas iktikad baik. ${ }^{25}$ Asas kebebasan berkontrak merupakan asas yang menduduki posisi sentral di dalam hukum perjanjian, meskipun asas ini tidak dituangkan menjadi aturan hukum namun mempunyai pengaruh sangat

16 Ricardo Simanjuntak, Op.cit., hlm. 115.

17 Ibid., hlm. 115-116.

18 Ibid., hlm. 116.

19 Ibid.

20 Agus Yudha Hernoko, Hukum Perjanjian Asas Proporsionalitas dalam Kontrak Komersil, Kencana Prenada Media Group, Jakarta, 2011, hlm. 102.

21 Ibid., hlm. 102-103.

22 Ibid., hlm. 103.

23 Ibid.

24 Ibid.

25 Salim H.S., Hukum Kontrak Teori \& Teknik Penyusunan Kontrak, Sinar Grafika, Jakarta, 2011, hlm. 9. 
kuat dalam hubungan kontraktual para pihak. ${ }^{26}$ Kebebasan berkontrak pada dasarnya merupakan perwujudan dari kehendak bebas, pancaran hak asasi manusia yang perkembangannya dilandasi semangat liberalisme yang mengagungkan kebebasan individu. ${ }^{27}$ Menurutasas kebebasan berkontrak, seseorang pada umumnya mempunyai pilihan bebas untuk mengadakan perjanjian. ${ }^{28} \mathrm{Di}$ dalam asas ini terkandung suatu pandangan bahwa orang bebas untuk melakukan atau tidak melakukan perjanjian, bebas dengan siapa ia mengadakan perjanjian, bebas tentang apa yang diperjanjikan dan bebas untuk menetapkan syarat-syarat perjanjian. ${ }^{29}$

Asas konsensualisme dapat disimpulkan dalam Pasal 1320 ayat (1) KUHPerdata. ${ }^{30}$ Dalam pasal itu ditentukan bahwa salah satu syarat sahnya perjanjian yaitu adanya kesepakatan kedua belah pihak. ${ }^{31}$ Asas konsensualisme merupakan asas yang menyatakan bahwa perjanjian pada umumnya tidak diadakan secara formal, tetapi cukup dengan adanya kesepakatan kedua belah pihak. ${ }^{32}$ Kesepakatan merupakan persesuaian antara kehendak dan pernyataan yang dibuat oleh kedua belah pihak. ${ }^{33}$ Asas konsensualisme memperlihatkan kepada kita semua, bahwa pada dasarnya suatu perjanjian yang dibuat secara lisan antara dua atau lebih orang telah mengikat, dan karenanya telah melahirkan kewajiban bagi salah satu atau lebih pihak dalam perjanjian tersebut, segera setelah orang-orang tersebut mencapai kesepakatan atau consensus, meskipun kesepakatan tersebut telah dicapai secara lisan semata-mata. ${ }^{34}$ Ini berarti pada prinsipnya perjanjian yang mengikat dan berlaku sebagai perikatan bagi para pihak yang berjanji tidak memerlukan formalitas, walau demikian, untuk menjaga kepentingan pihak debitor (atau yang berkewajiban untuk memenuhi prestasi) diadakanlah bentuk-bentuk formalitas, atau dipersyaratkan adanya suatu tindakan nyata tertentu. ${ }^{35}$

Asas iktikad baik dapat disimpulkan dari Pasal 1338 ayat (3) KUHPerdata yang berbunyi "Perjanjian harus dilaksanakan dengan iktikad baik." ${ }^{36}$ Asas iktikad baik merupakan asas bahwa para pihak harus melaksanakan substansi perjanjian berdasarkan kepercayaan atau keyakinan yang teguh atau kemauan baik

26 Agus Yudha Hernoko, Op.cit., hlm. 108.

27 Ibid., hlm. 109.

28 Ibid., hlm. 110.

29 Ibid.

30 Salim HS, Op.cit., hlm. 10.

31 Ibid.

32 Ibid.

33 Ibid.

34 Kartini Mulyadi dan Gunawan Wijaya, Perikatan yang Lahir dari Perjanjian, RajaGrafindo Persada, Jakarta, 2010, hlm. 34-35.

35 Ibid., hlm. 35.

36 Salim H.S., Perkembangan Hukum Kontrak Innominaat di Indonesia, Sinar Grafika, Jakarta, 2004, hlm. 11. 
dari para pihak. ${ }^{37}$ Iktikad baik juga dibedakan dalam sifatnya yang nisbi (relatif-subjektif) dan mutlak (absolut-objektif). ${ }^{38}$ Pada iktikad baik yang nisbi (relatif-subjektif), orang memperhatikan sikap dan tingkah laku yang nyata dari subjek. ${ }^{39}$ Pada iktikad baik yang absolut-objektif atau hal sesuai dengan akal sehat dan keadilan, dibuat objektif untuk menilai keadaan sekitar perbuatan hukumnya (penilaian tidak memihak menurut normanorma yang objektif) ${ }^{40}$.

Di dalam suatu perjanjian, tidak selamanya dapat berjalan dengan lancar. Terkadang muncul perselisihan ataupun perbedaan pendapat diantara para pihak. Seperti yang terjadi dalam Perjanjian Jual Beli Saham PT Kaltim Satria Samudra (PT KSS) antara Pihak Penjual yaitu Yayasan Kesejahteraan Hari Tua (YKHT) dengan Yayasan Pupuk Kaltim (YPK). Perjanjian ini bermula dari surat permohonan dari YPK (Surat Nomor : 1.184/SEKR-YPK/XII.2010) kepada YKHT tanggal 30 Desember 2010 untuk membeli saham PT KSS yang dimiliki oleh YKHT. Setelah beberapa proses negoisasi, akhirnya terjadi Kesepakatan Rencana Jual Beli Saham PT KSS antara YKHT dan YPK pada 15 Mei 2012 dengan point-point kesepakatan sebagai berikut:

1. Harga Saham Rp. 110.00.000,- (seratus sepuluh juta rupiah) per lembar belum

37 Ibid.

38 Agus Yudha Hernoko, Op.cit., hlm. 136.

39 Ibid., hlm. 136-137.

40 Ibid., hlm. 137. termasuk PPN.

2. Komposisi $100 \%$.

3. Cara Pembayaran paling lambat tanggal 30 Juni 2012.

4. Jika pembayaran setelah tanggal 30 Juni 2012, sepakat dikenakan perhitungan bunga teknis sebesar 9\% (sembilan persen) per tahun, paling lama tanggal 31 Desember 2012.

5. Dalam hal tanggal 31 Desember 2012 belum lunas, YPK bersedia diperhitungkan penalty sebesar $2 \%$ (dua persen) per bulan dihitung dari saldo.

Setelah melalui perhitungan, maka diketahui total nilai saham PT KSS adalah sebesar Rp. 11.000.000.000,- (sebelas milyar rupiah). YPK kemudian melakukan pembayaran secara bertahap, dan hingga tanggal 31 Juli 2012 telah membayar sebesar Rp. 5.000.000.000,- (lima milyar rupiah).

Pada 6 Desember 2012, YPK mengirimkan surat ke YKHT (Surat Nomor: 1.121/ SEKR-YPK/XII.2012 tentang Pembatalan Pembelian Saham PT KSS. Adapun hal-hal yang menjadi pertimbangan dari YPK adalah sebagai berikut:

1. Kesepakatan harga pembelian PT KSS tersebut didasarkan pada hasil appraisal pihak ketiga yang dilakukan oleh YKHT dengan asumsi prospek bisnis PT KSS saat itu yang masih menjanjikan (bersifat 
captive, dengan asumsi profit bersih sekitar Rp. 5 Milyar per tahun)

2. Dengan kondisi prospek bisnis PT KSS yang berubah drastis saat ini (karena dengan adanya perubahan kebijakan terhadap tender Pelabuhan Bongkar Muat di PT Pupuk Kalimantan Timur(PKT)), maka hasil appraisal tersebut sudah tidak bisa dijadikan dasar untuk kesepakatan harga jual beli karena prospek bisnis PT KSS sudah turun drastis (Mengacu Rencana Kerja Anggaran Perusahaan PT KSS tahun 2012 yang menargetkan keuntungan profit bersih sebesar Rp. 1 Milyar per tahun)

Melalui surat tanggal 6 Desember 2012 tersebut, YPK meminta pembatalan perjanjian jual beli saham PT KSS tersebut. YPK juga meminta YKHT mengembalikan uang yang telah diserahkan YPK yaitu sebesar Rp 5.000.000.000,- (lima milyar rupiah) paling lambat tanggal 6 Januari 2013.

YPK dan YKHT kemudian melakukan negoisasi mengenai pembatalan perjanjian jual beli saham PT KSS tersebut. Namun yang menjadi permasalahan, kesepakatan rencana pembelian saham PT KSS yang ditandatangi oleh YPK dan YKHT tidak mencantumkan syarat pembatalan perjanjian tersebut. Ketiadaan syarat batal dalam perjanjian tersebut membuat negoisasi pembatalan jual beli saham PT KSS menjadi deadlock. YKHT pun merasa keberatan untuk mengembalikan dana sebesar Rp. 5.000.000.000,- (lima milyar rupiah) yang telah disetorkan oleh YPK. Hal yang menarik untuk diteliti yaitu apa solusi hukum yang ditempuh untuk menyelesaikan sengketa pembatalan perjanjian jual beli saham secara sepihak di antara Pemegang Saham PT Kaltim Satria Samudera. Selain itu, hal lain yang menarik untuk diteliti yaitu apa akibat hukum yang timbul dari pembatalan perjanjian jual beli saham PT Kaltim Satria Samudera yang dilakukan secara sepihak tersebut.

Tulisan ini merupakan hasil penelitian hukum normative, dengan menggunakan pendekatan perundang-undangan dan pendekatan kasus yang mengkaji peraturan perundang-undangan yang berkaitan dengan Perjanjian yaitu Kitab Undang-Undang Hukum Perdata (KUHPerdata) dan yang berkaitan dengan Perseroan Terbatas yaitu Undang Undang nomor 40 tahun 2007 tentang Perseroan Terbatas serta peraturan terkait lainnya. Bahan hukum yang digunakan yakni bahan hukum primer berupa KUHPerdata dan Undang-undang Nomor 40 Tahun 2007 tentang Perseroan Terbatas. Sedangkan bahan hukum sekunder berupa buku, makalah dan literatur lainnya terkait dengan permasalahan. Bahan hukum tersebut kemudian dianalisis dengan metode interpretasi. 


\section{Pembahasan}

A. Penyelesaian Kasus Sengketa Pengajuan Pembatalan Perjanjian Jual Beli Saham PT Kaltim Satria Samudera

Sengketa pengajuan pembatalan perjanjian jual beli saham PT Kaltim Satria Samudera secara umum dapat diselesaikan dengan 2 (dua) cara yaitu:

1. Penyelesaian sengketa melalui Pengadilan

2. Alternatif Penyelesaian Sengketa (Alternative Dispute Resolutions), yaitu dapat berupa Mediasi, Arbitrase dan Negosiasi

Penyelesaian sengketa, selain dilakukan melalui pengadilan (litigasi) juga dapat diselesaikan di luar pengadilan (non litigasi), yang lazim dinamakan dengan Alternative Dispute Resolution (ADR) atau Alternatif Penyelesaian Sengketa. ${ }^{41}$ Penyelesaian sengketa melalui pengadilan berpedoman pada Hukum Acara yang mengatur persyaratanpersyaratan yang harus dipenuhi agar suatu sengketadapatdiajukansertaupaya-upayayang dapat dilakukan. ${ }^{42}$ Penyelesaian sengketa di luar pengadilan adalah penyelesaian sengketa yang dilakukan berdasarkan kesepakatan para pihak dan prosedur penyelesaian atas suatu sengketa diserahkan sepenuhnya kepada para pihak yang bersengketa. Penyelesaian sengketa di luar pengadilan dapat dilakukan melalui berbagai cara, di antaranya negosiasi, mediasi, konsiliasi dan arbitrase. Penyelesaian sengketa tersebut memiliki kelebihan dan kekurangan masing-masing yang dapat dijadikan pertimbangan oleh para pihak dalam memilih cara menyelesaikan sengketa. ${ }^{43}$

Alternatif Penyelesaian Sengketa atau Alternative Dispute Resolution (ADR), adalah suatu bentuk penyelesaian sengketa di luar pengadilan berdasarkan kata sepakat (consensus) yang dilakukan oleh para pihak yang bersengketa baik tanpa ataupun bantuan pihak ketiga yang netral. ${ }^{44}$

ADR adalah suatu pranata penyelesaian sengketa di luar pengadilan, yang mekanismenya berdasarkan sebuah kesepakatan para pihak dengan mengesampingkan penyelesaian sengketa secara litigasi di pengadilan, baik itu dilakukan secara negosiasi, mediasi dan konsiliasi. ${ }^{45}$ ADR ini merupakan suatu penyelesaian sengketa yang dilakukan sendiri oleh para pihak yang bersengketa dengan atau tanpa bantuan orang lain yang akan membantu menyelesaikan sengketa atau beda pendapat diantara para pihak yang bersengketa. Berbeda dengan litigasi, penyelesaian sengketa

41 Rachmadi Usman, Mediasi di Pengadilan dalam Teori dan Praktik, Sinar Grafika, Jakarta, 2012, hlm. 8.

42 Jimmy Joses Sembiring, Cara Menyelesaikan Sengketa di Luar Pengadilan, Visimedia, Jakarta, 2011, hlm. 2.

43 Ibid.

44 Rachmadi Usman, Op.cit., hlm. 2.

45 Ibid., hlm. 10. 
melalui ADR ini berada di tangan para pihak yang bersengketa. ADR ini hanya dapat ditempuh bilamana para pihak menyepakati penyelesaiannya melalui pranata pilihan penyelesaian sengketa. ${ }^{46}$

Masing-masing penyelesaian sengketa tersebut memiliki keunggulan dan kelemahan sebagai berikut ${ }^{47}$ :

1. Penyelesaian sengketa melalui litigasi dapat dikatakan sebagai penyelesaian sengketa yang memaksa salah satu pihak untuk menyelesaikan sengketa dengan perantaraan pengadilan, sedangkan penyelesaian sengketa melalui non litigasi dilakukan dengan berdasar pada kehendak dan iktikad baik dari para pihak untuk menyelesaikan sengketa.

2. Penyelesaian sengketa melalui litigasi memiliki sifat eksekutorial dalam arti pelaksanaan terhadap putusan dapat dipaksakan oleh lembaga yang berwenang. Sedangkan dalam penyelesaian sengketa melalui non litigasi tidak dapat dipaksakan pelaksanaannya sebab bergantung pada kehendak dan iktikad baik dari para pihak.

3. Penyelesaian sengketa melalui litigasi pada umumnya dilakukan dengan menyewa jasa dari advokat/pengacara sehingga biaya yang harus dikeluarkan tentunya besar.

4. Penyelesaian sengketa melalui litigasi tentu harus mengikuti persyaratan- persyaratan dan prosedur-prosedur formal di pengadilan dan sebagai akibatnya jangka waktu untuk menyelesaikan suatu sengketa menjadi lebih lama. Sedangkan penyelesaian sengketa melalui non litigasi tidak mempunyai prosedur-prosedur atau persyaratan-persyaratan formal sebab bentuk dan tata cara penyelesaian sengketa diserahkan sepenuhnya kepada para pihak.

5. Penyelesaian sengketa pada proses litigasi yang bersifat terbuka mengandung makna bahwa siapa saja dapat menyaksikan jalannya persidangan, terkecuali untuk perkara tertentu, misalnya perkara asusila. Sedangkan sifat rahasia dari penyelesaian sengketa melalui non litigasi berarti hanya pihak-pihak yang bersengketa yang dapat menghadiri persidangan dan bersifat tertutup untuk umum sehingga segala hal yang diungkap pada pemeriksaan, tidak dapat diketahui oleh khalayak ramai dengan maksud menjaga reputasi dari para pihak yang bersengketa.

Pemilihan cara dalam penyelesaian sengketa sangat bergantung pada kondisi dan kesepakatan kedua belah pihak. Pemilihan cara penyelesaian sengketa pengajuan pembatalan perjanjian jual beli saham PT Kaltim Satria Samudera tersebut dapat dilakukan dengan menggunakan pisau analisis teori sistem hukum (legal system theory) yang 
menyatakan bahwa suatu sistem hukum terdiri dari struktur hukum, substansi hukum dan budaya hukum. Efektifitas penerapan hukum sangat dipengaruhi oleh ketiga unsur dalam sistem hukum tersebut. Berikut merupakan analisis metode penyelesaian sengketa yang ada (Pengadilan, mediasi, mediasi, negosiasi) berdasarkan teori sistem hukum:

\section{Penyelesaian sengketa lewat pengadilan}

Litigasi merupakan suatu proses gugatan atas suatu konflik yang diritualisasikan yang menggantikan konflik sesungguhnya, dimana para pihak dengan memberikan kepada seorang pengambil keputusan dua pilihan yang bertentangan. ${ }^{48}$ Litigasi merupakan proses yang sangat dikenal (familiar) bagi masyarakat, dengan karakteristik adanya pihak ketiga yang mempunyai kekuatan untuk memutuskan (to impose) solusi diantara para pihak yang bersengketa. ${ }^{49}$

Litigasi diartikan sebagai proses administrasi dan peradilan (court and administrative proceedings). Dalam mengambil alih keputusan dari para pihak, litigasi sekurang-kurangnya dalam batas tertentu menjamin bahwa kekuasaan tidak dapat mempengaruhi hasil dan dapat menjamin ketentraman sosial. Sebagai suatu ketentuan umum, sebagai suatu proses gugatan, litigasi sangat baik sekali untuk menemukan kesalahan-kesalahan dan masalah-masalah dalam posisi pihak lawan. Litigasi juga memberikan suatu standar bagi prosedur yang adil dan memberikan peluang yang luas kepada para pihak untuk didengar keterangannya sebelum diambil keputusan. ${ }^{50}$

Berdasarkan teori sistem hukum, penyelesaian sengketa pembatalan jual beli saham PT Kaltim Satria Samudera melalui Pengadilan dapat dianalisis sebagai berikut:

a. Berdasarkan struktur hukum

Berdasarkan struktur hukum, penyelesaian sengketa pengajuan pembatalan jual beli saham PT Kaltim Satria Samudera lewat pengadilan dapat dianalisis sebagai berikut:

1) Telah ada sistem peradilan yang jelas untuk menyelesaikan sengketa tersebut.

2) Putusannya mengikat, sehingga dapat langsung dijalankan (eksekusi).

b. Berdasarkan substansi hukum

Berdasarkan substansi hukum, penyelesaian sengketa pengajuan pembatalan jual beli saham PT Kaltim Satria Samudera lewat pengadilan dapat dianalisis sebagai berikut:

1) Telah adanya ketentuan hukum yang jelas mengenai kaidah hukum perjanjian dan hal-hal yang memungkinkan terjadinya sengketa antara para pihak.

2) Telah adanya ketentuan hukum yang jelas untuk mengatur tata cara penyelesaian sengketa di pengadilan.

48 Suyud Margono, Penyelesaian Sengketa Bisnis, Ghalia Indonesia, Bogor, 2010, hlm. 17.

49 Ibid.

50 Ibid., hlm. 17-18. 
c. Berdasarkan budaya hukum

Berdasarkan Budaya hukum, penyelesaian sengketa pengajuan pembatalan jual beli saham PT Kaltim Satria Samudera lewat pengadilan dapat dianalisis sebagai berikut:

1. Pola hubungan yang terbentuk antara 2 (dua) pihak adalah saling melawan antara kedua belah pihak. Hal ini tentunya tidak sesuai dengan pola hubungan dan budaya yang ada di kedua belah pihak. Pihak yang bersengketa yaitu Yayasan Pupuk Kaltim (YPK) dan Yayasan Kesejahteraan Hari Tua (YKHT) Pupuk Kaltim adalah Yayasan yang bergerak untuk memenuhi kebutuhan pemangku kepentingan (stakeholders) Pupuk Kaltim. YPK bergerak untuk memenuhi aspek kebutuhan pendidikan dari anak Karyawan Pupuk Kaltim yaitu dengan mendirikan sekolah (SD, SMP dan SMA) di area perumahan Karyawan Pupuk Kaltim. YKHT bergerak untuk mengelola pendanaan bagi berjalanannya Program Kesehatan Pensiun untuk pensiunan Karyawan Pupuk Kaltim.

2. Pembina, pengawas dan pengurus harian YPK dan YKHT merupakan Karyawan di Pupuk Kaltim, sehingga merupakan pihak yang saling berhubungan baik dalam hal hubungan pekerjaan maupun hubungan personal. Penyelesaian sengketa melalui Pengadilan akan memicu konflik yang lebih mendalam antara pihak-pihak yang masih berstatus sebagai Karyawan Pupuk Kaltim.

3. Putusan yang dihasilkan lewat Pengadilan cenderung merupakan solusi kalahmenang (win-lose solution), sehingga tidak dapat mengakomodir kepentingan bisnis antara kedua belah pihak yang saling berhubungan.

\section{Penyelesaian sengketa lewat mediasi}

Mediasi adalah proses negosiasi pemecahan masalah dimana pihak luar yang tidak memihak (Impartial) dan netral bekerja dengan pihak yang bersengketa untuk membantu mereka memperoleh kesepakatan perjanjian dengan memuaskan. Berbeda dengan hakim atau arbiter, mediator tidak memiliki kewenangan untuk memutuskan sengketa antara para pihak, namun dalam hal ini para pihak menguasakan kepada mediator untuk membantu mereka menyelesaikan persoalan-persoalan diantara mereka. ${ }^{51}$ Pada dasarnya mediasi adalah cara penyelesaian sengketa di luar pengadilan melalui perundingan yang melibatkan pihak ketiga yang bersikap netral (nonintervensi) dan tidak berpihak (impartial) kepada pihak-pihak yang bersengketa serta diterima kehadirannya oleh pihak-pihak yang bersengketa. ${ }^{52}$ Pihak ketiga dalam mediasi tersebut disebut "mediator" atau "penengah, yang tugasnya hanya membantu pihak-pihak yang bersengketa 
dalam menyelesaikan masalahnya dan tidak mempunyai kewenangan untuk mengambil keputusan. Mediator disini hanya bertindak sebagai fasilitator saja. Dengan demikian diharapkan dicapai titik temu penyelesaian masalah atau sengketa yang dihadapi para pihak, yang selanjutnya akan dituangkan sebagai kesepakatan bersama. Pengambil keputusan tidak berada di tangan mediator, melainkan di tangan para pihak yang bersengketa. $^{53}$

Berdasarkan teori sistem hukum, penyelesaian sengketa pembatalan jual beli saham PT Kaltim Satria Samudera melalui Mediasi dapat dianalisis sebagai berikut:

a. Berdasarkan struktur hukum

Berdasarkan struktur hukum, penyelesaian sengketa pengajuan pembatalan jual beli saham PT Kaltim Satria Samudera melalui Mediasi dapat dianalisis sebagai berikut:

1) Struktur hukum yang diperlukan adalah mediator, dalam hal ini para pihak yang bersengketa dapat mengajukan mediator yang kemudian disepakati untuk memandu mediasi antara kedua belah pihak.

2) Tidak ada alat penegak hukum untuk memastikan terlaksananya keputusan dari mediasi, sehingga memerlukan iktikad baik dari para pihak untuk memastikan dilaksanakannya hasil keputusan mediasi.

b. Berdasarkan substansi hukum
Berdasarkan substansi hukum, penyelesaian sengketa pengajuan pembatalan jual beli saham PT Kaltim Satria Samudera melalui mediasi dapat dianalisis sebagai berikut:

1) Telah adanya ketentuan hukum yang mengatur secara umum mengenai mediasi, yaitu Undang-undang Nomor 30 Tahun 1999 tentang Arbitrase dan Alternatif Penyelesaian Sengketa.

2) Ketentuan teknis lebih lanjut mengenai mediasi dapat disepakati oleh para pihak.

c. Berdasarkan Budaya Hukum

Berdasarkan Budaya hukum, penyelesaian sengketa pengajuan pembatalan jual beli saham PT Kaltim Satria Samudera melalui mediasi dapat dianalisis sebagai berikut:

1) Pola hubungan yang terbentuk antara 2 (dua) pihak adalah pencarian solusi yang mengakomodir kedua belah pihak. Hal ini tentunya sesuai dengan pola hubungan dan budaya yang ada di kedua belah pihak. Pihak yang bersengketa yaitu Yayasan Pupuk Kaltim (YPK) dan Yayasan Kesejahteraan Hari Tua (YKHT) Pupuk Kaltim adalah Yayasan yang bergerak untuk memenuhi kebutuhan pemangku kepentingan (stakeholders) Pupuk Kaltim.

2) Pembina, pengawas dan pengurus harian YPK dan YKHT merupakan Karyawan di Pupuk Kaltim, sehingga merupakan pihak 
yang saling berhubungan baik dalam hal hubungan pekerjaan maupun hubungan personal. Penyelesaian sengketa melalui mediasi akan tetap mempertahankan hubungan baik antara para pihak yang masih berstatus sebagai Karyawan Pupuk Kaltim.

3) Putusan yang dihasilkan lewat mediasi cenderung merupakan solusi menangmenang (win-win solution), sehingga dapat mengakomodir kepentingan bisnis antara kedua belah pihak yang saling berhubungan.

\section{Penyelesaian sengketa lewat arbitrase}

Arbitrase adalah cara penyelesaian sengketa di luar lembaga litigasi atau peradilan yang diadakan oleh para pihak yang bersengketa atas dasar perjanjian atau kontrak yang telah mereka adakan sebelumnya atau sesudah terjadinya sengketa. ${ }^{54}$ Para pemutus atau arbiternya dipilih dan ditentukan oleh para pihak yang bersengketa dengan tugas menyelesaikan persengketaan yang terjadi di antara mereka. Pemilihan arbiter semestinya didasarkan pada kemampuan dan keahliannya dalam bidang tertentu dan dapat bertindak secara netral. ${ }^{55}$

Berdasarkan teori sistem hukum, penyelesaian sengketa pembatalan jual beli saham PT Kaltim Satria Samudera melalui arbitrase dapat dianalisis sebagai berikut: a. Berdasarkan struktur hukum

Berdasarkan struktur hukum, penyelesaian sengketa pengajuan pembatalan jual beli saham PT Kaltim Satria Samudera melalui Arbitrase dapat dianalisis sebagai berikut:

1) Struktur hukum yang diperlukan adalah Arbiter, dalam hal ini para pihak yang bersengketa dapat mengajukan Arbiter yang kemudian disepakati untuk memandu Arbitrase antara kedua belah pihak.

2) Terdapat dua jenis arbitrase yang dapat dipilih para pihak untuk menyelesaikan sengketanya yaitu arbitrase ad hoc (volunteer) dan arbitrase institusional (permanent). Kedua arbitrase tersebut sama-sama mempunyai wewenang untuk mengadili dan memutus sengketa yang terjadi antara para pihak yang mengadakan perjanjian di bidang perdagangan dan hak. Perbedaan antara kedua jenis arbitrase ini terletak pada terkoordinasi atau tidak terkoordinasi. Arbitrase ad hoc adalah arbitrase yang tidak terkoordinasi oleh suatu lembaga sedangkan arbitrase institusional adalah suatu arbitrase yang dikoordinasikan oleh lembaga, seperti Badan Arbitrase Nasional Indonesia (BANI), Badan Arbitrase Syariah Nasional (Basyarnas) dan Badan Arbitrase Pasar Modal Indonesia (Bapmi). 
b. Berdasarkan substansi hukum

Berdasarkan substansi hukum, penyelesaian sengketa pengajuan pembatalan jual beli saham PT Kaltim Satria Samudera melalui arbitrase dapat dianalisis sebagai berikut:

1) Telah adanya ketentuan hukum yang mengatur secara umum mengenai arbitrase, yaitu Undang-undang Nomor 30 Tahun 1999 tentang Arbitrase dan Alternatif Penyelesaian Sengketa.

2) Ketentuan teknis lebih lanjut mengenai arbitrase dapat diatur dalam klausulaklausula arbitrase yang disepakati oleh para pihak.

c. Berdasarkan budaya hukum

Berdasarkan Budaya hukum, penyelesaian sengketa pengajuan pembatalan jual beli saham PT Kaltim Satria Samudera melalui arbitrase dapat dianalisis sebagai berikut:

1) Pola hubungan yang terbentuk antara 2 (dua) pihak adalah saling melawan antara kedua belah pihak. Hal ini tentunya tidak sesuai dengan pola hubungan dan budaya yang ada di kedua belah pihak. Pihak yang bersengketa yaitu Yayasan Pupuk Kaltim (YPK) dan Yayasan Kesejahteraan Hari Tua (YKHT) Pupuk Kaltim adalah Yayasan yang bergerak untuk memenuhi kebutuhan pemangku kepentingan (stakeholders) Pupuk Kaltim. YPK bergerak untuk memenuhi aspek kebutuhan pendidikan dari anak
Karyawan Pupuk Kaltim yaitu dengan mendirikan sekolah (SD, SMP dan SMA) di area perumahan Karyawan Pupuk Kaltim. YKHT bergerak untuk mengelola pendanaan bagi berjalanannya Program Kesehatan Pensiun untuk pensiunan Karyawan Pupuk Kaltim.

2) Pembina, pengawas dan pengurus harian YPK dan YKHT merupakan Karyawan di Pupuk Kaltim, sehingga merupakan pihak yang saling berhubungan baik dalam hal hubungan pekerjaan maupun hubungan personal. Penyelesaian sengketa melalui Arbitrase akan memicu konflik yang lebih mendalam antara pihak-pihak yang masih berstatus sebagai Karyawan Pupuk Kaltim.

3) Putusan yang dihasilkan lewat Arbitrase cenderung merupakan solusi kalahmenang (win-lose solution), sehingga tidak dapat mengakomodir kepentingan bisnis antara kedua belah pihak yang saling berhubungan.

\section{Penyelesaian sengketa lewat negosiasi}

Negosiasi merupakan proses konsensus yang digunakan para pihak untuk memperoleh kesepakatan diantara mereka. Negosiasi menurut Fsiher dan Ury(1991) merupakan komunikasi dua arah yang dirancang untuk mencapai kesepakatan pada saat kedua belah pihak memiliki berbagai kepentingan yang sama maupun berbeda ${ }^{56}$. Negosiasi 
merupakan sarana bagi pihak-pihak yang mengalami sengketa untuk mendiskusikan penyelesaiannya tanpa melibatkan pihak ketiga penengah yang tidak berwenang mengambil keputusan (mediasi), maupun pihak ketiga pengambil keputusan (arbitrase dan litigasi). ${ }^{57}$

Negosiasi merupakan bentuk penyelesaian sengketa yang paling sederhana, karena tidak perlu melibatkan orang lain atau pihak ketiga. ${ }^{58}$ Semua tahapan dalam negosiasi ditentukan berdasarkan pola komunikasi yang dimilikinya sendiri, mulai dari proses pertemuan sampai kepada penentuan nilai-nilai penawaran dilakukan berdasarkan kehendak dan inisiatif pribadi. Di samping berfungsi sebagai cara penyelesaian sengketa, negosiasi juga dalam praktik dunia usaha atau perdagangan dan hubungan internasional memiliki fungsi lain, yaitu fungsi untuk menghasilkan kontrakkontrak atau perjanjian-perjanjian tanpa dilatarbelakangi oleh adanya perselisihan terlebih dahulu. ${ }^{59}$

Penyelesaian sengketa melalui negosiasi ini merupakan perundingan atau pertemuan langsung yang dilakukan oleh para pihak yang bersengketa tanpa keterlibatan pihak ketiga atau penengah. ${ }^{60}$ Para pihak yang bersengketa yang secara langsung melakukan perundingan atau tawar-menawar, sehingga menghasilkan suatu kesepakatan bersama.
Para pihak yang bersengketa sudah tentu telah berdiskusi atau bermusyawarah sedemikian rupa agar kepentingan-kepentingan dan hak-haknya terakomodir menjadi kepentingan atau kebutuhan bersama para pihak yang bersengketa. Pada umumnya kesepakatan bersama tersebut dituangkan secara tertulis. ${ }^{61}$

Berdasarkan teori sistem hukum, penyelesaian sengketa pembatalan jual beli saham PT Kaltim Satria Samudera melalui Negosiasi dapat dianalisis sebagai berikut:

a. Berdasarkan struktur hukum

Berdasarkan struktur hukum, penyelesaian sengketa pengajuan pembatalan jual beli saham PT Kaltim Satria Samudera melalui negosiasi dapat dianalisis sebagai berikut:

1) Tidak memerlukan peran serta pihak lain di luar pihak yang bersengketa.

2) Para pihak yang berperan menjadi struktur hukum untuk penyelesaian sengketa dan pelaksanaan perjanjian.

b. Berdasarkan substansi hukum

Berdasarkan substansi hukum, penyelesaian sengketa pengajuan pembatalan jual beli saham PT Kaltim Satria Samudera dapat diatur dalam tata cara negosiasi dan hasil negosiasi dilakukan berdasarkan kesepakatan para pihak

c. Berdasarkan budaya hukum

Berdasarkan Budaya hukum, penyelesaian

57 Ibid., hlm. 22.

58 Rachmadi Usman, Op.cit., hlm. 21.

59 Ibid.

60 Ibid.

61 Ibid. 
sengketa pengajuan pembatalan jual beli saham PT Kaltim Satria Samudera melalui negosiasi dapat dianalisis sebagai berikut:

1) Pola hubungan yang terbentuk antara 2 (dua) pihak adalah pencarian solusi yang mengakomodir kedua belah pihak. Hal ini tentunya sesuai dengan pola hubungan dan budaya yang ada di kedua belah pihak. Pihak yang bersengketa yaitu Yayasan Pupuk Kaltim (YPK) dan Yayasan Kesejahteraan Hari Tua (YKHT) Pupuk Kaltim adalah Yayasan yang bergerak untuk memenuhi kebutuhan pemangku kepentingan (stakeholders) Pupuk Kaltim.

2) Pembina, pengawas dan pengurus harian YPK dan YKHT merupakan Karyawan di Pupuk Kaltim, sehingga merupakan pihak yang saling berhubungan baik dalam hal hubungan pekerjaan maupun hubungan personal. Penyelesaian sengketa melalui negosiasi akan tetap mempertahankan hubungan baik antara para pihak yang masih berstatus sebagai Karyawan Pupuk Kaltim.

3) Putusan yang dihasilkan lewat Negosiasi cenderung merupakan solusi menangmenang (win-win solution), sehingga dapat mengakomodir kepentingan bisnis antara kedua belah pihak yang saling berhubungan.

Berdasarkan analisis teori sistem hukum maka penyelesaian sengketa yang dapat ditempuh para pihak untuk menyelesaikan sengketa pembatalan jual beli saham PT
Kaltim Satria Samudera adalah melalui negosiasi dan mediasi dengan beberapa pertimbangan sebagai berikut:

1. Berdasarkan Struktur hukum, penyelesaian sengketa memungkinkan untuk dapat dilakukan berdasarkan negosiasi dan mediasi. Dalam negosiasi, struktur hukum yang berperan adalah para pihak yang bersengketa. Para pihak tersebutlah yang menjamin terlaksananya hasil negosiasi dengan penuh iktikad baik. Dalam mediasi, Para pihak dapat menunjuk mediator untuk menengahi. Dalam hal ini maka disarankan para pihak dapat melibatkan mediator dari pihak internal Pupuk Kaltim, seperti General Manager SDM PT Pupuk Kaltim sebagai pihak yang netral.

2. Berdasarkan substansi hukum, ketentuan yang ada memungkinkan diadakan penyelesaian sengketa melalui negosiasi dan mediasi.

3. Berdasarkan Budaya hukum, penyelesaian sengketa melalui negosiasi dan mediasi merupakan yang paling tepat dengan budaya hukum di Pihak YPK dan YKHT. Sebagai Yayasan yang sama-sama bergerak untuk memenuhi kebutuhan pemangku kepentingan (stakeholders) Pupuk Kaltim, cara penyelesaian sengketa lewat Negosiasi dan Mediasi dinilai paling sesuai dengan budaya hukum yang ada. Negosiasi dan Mediasi cenderung bersifat win-win solution sehingga dapat mengakomodir 
kepentingan para pihak. Selain itu, Negosiasi dan Mediasi cenderung dapat menjaga hubungan baik diantara para pihak sesama pemangku kepentingan (stakeholders) Pupuk Kaltim.

Setiap masyarakat memiliki struktur dan substansi hukum sendiri, yang menentukan apakah substansi dan struktur hukum tersebut ditaati atau sebaliknya juga dilanggar adalah sikap dan perilaku sosial masyarakatnya dan karena itu untuk memahami apakah hukum itu menjadi efektif atau tidak sangat tergantung pada kebiasaan-kebiasaan (customs), kultur (culture), tradisi-tradisi (traditions) dan norma-norma informal (informal norms) yang diciptakan dan dioperasionalkan dalam masyarakat yang bersangkutan. ${ }^{62}$

Dengan mengkaji komponen struktur hukum, subtansi hukum dan budaya hukum sebagai suatu sistem hukum, maka dapat dicermati bagaimana suatu sistem hukum bekerja dalam masyarakat, atau bagaimana sistem-sistem hukum dalam konteks pluralisme hukum saling berinteraksi dalam suatu bidang kehidupan sosial (social field) tertentu. ${ }^{63}$ Budaya hukum menjadi bagian dari kekuatan sosial yang menentukan efektif atau tidaknya hukum dalam kehidupan masyarakat. ${ }^{64}$ Budaya hukum menjadi motor penggerak dan memberi masukan-masukan kepada struktur dan substansi hukum dalam

\section{B. Akibat Hukum yang Timbul dari Pembatalan Perjanjian Jual Beli Saham PT Kaltim Satria Samudera}

Teori Pacta Sunt Servanda mengajarkan bahwa terhadap suatu kontrak yang dibuat secara sah dan sesuai hukum yang berlaku, serta sesuai pula dengan kebiasaan dan kelayakan, sehingga diasumsikan sebagai kontrak yang dibuat dengan iktikad baik, maka klausula-klausula dalam kontrak seperti itu mengikat para pihak yang membuatnya, dimana kekuatan mengikatnya setara dengan kekuatan mengikatnya undang-undang. Ditinjau dari sudut pandang hukum perjanjian, pembatalan perjanjian dapat dilakukan karena hal-hal sebagai berikut:

1. Batal karena kesepakatan para pihak.

2. Batal karena tidak terpenuhinya persyaratan yang ditetapkan oleh Undang-undang untuk jenis perjanjian formil, yang berakibat perjanjian batal demi hukum.

3. Batal karena tidak terpenuhinya syarat sahnya perjanjian, yang berakibatPerjanjian batal demi hukum ataudapat dibatalkan.

4. Batal karena terpenuhinya syarat batal pada jenis perjanjian yang bersyarat.

62 I Nyoman Nurjaya, Perkembangan Pemikiran Konsep Pluralisme Hukum, makalah untuk dipresentasikan dalam Konferensi Internasional tentang Penguasaan Tanah dan Kekayaan Alam di Indonesia yang sedang berubah: "Mempertanyakan Kembali Berbagai Jawaban", Jakarta, 11-13 Oktober 2004, hlm. 13.

63 Ibid.

64 Ibid 
5. Batal karena pembatalan oleh pihak ketiga atas dasar actio pauliana.

6. Batal karena pembatalan oleh pihak yang diberi wewenang khusus berdasarkan undang-undang.

Perjanjian jual beli saham PT Kaltim Satria Samudera tidak dapat dibatalkan secara sepihak.Cara pembatalan perjanjian yang dapat dilakukan secara hukum yaitu pertama dengan melakukan perjanjian baru yang disepakati para pihak untuk membatalkan perjanjian sebelumnya.Pembatalan tersebut sah secara hukum dan berlaku mengikat bagi para pihak.Akibat hukum dari pembatalan perjanjian tersebut yaitu mengakibatkan perjanjian sebelumnya tidak memiliki dampak dan implikasi hukum apapun dan ketentuan yang mengikat kedua belah pihak mengacu pada perjanjian baru yang disepakati oleh para pihak, termasuk mengenai pembatalan perjanjian jual beli saham PT Kaltim Satria Samudera.Cara kedua yaitu dengan mengajukan pembatalan perjanjian lewat Pengadilan. Dampak hukumnya yaitu perjanjian batal dan keadaan dikembalikan sebagaimana keadaan semula sebelum adanya perjanjian jual beli saham PT Kaltim Satria Samudera.

\section{Simpulan}

1. Teori Sistem hukum (legal system theory) mengajarkan bahwa sistem hukum terdiri dari struktur hukum, substansi hukum dan budaya hukum. Penegakan substansi hukum oleh struktur hukum akan dipengaruhi oleh budaya hukum, yaitu sikap dan perilaku sosial masyarakatnya. Pemahaman mengenai budaya hukum dapat membantu dalam efektivitas penegakan hukum yang berlaku. Dalam kasus sengketa pengajuan pembatalan jual beli saham PT Kaltim Satria Samudera, penerapan budaya hukum untuk memilih metode penyelesaian sengketa akan dapat membantu efektivitas penegakan hukum. Dalam hal ini, terdapat 2 (dua) cara penyelesaian sengketa yang dianjurkan yaitu melalui negosiasi dan mediasi. Pertimbangan paling kuat dalam memilih metode penyelesaian sengketa melalui negosiasi dan mediasi yaitu berdasarkan budaya hukum, negosiasi dan mediasi merupakan cara yang paling tepat dengan budaya hukum yang ada di pihak yang bersengketa yaitu YPK dan YKHT. Kedua Yayasan tersebut sama-sama bergerak untuk memenuhi kebutuhan pemangku kepentingan (stakeholders) Pupuk Kaltim. Negosiasi dan Mediasi cenderung bersifat win-win solution sehingga dapat mengakomodir kepentingan para pihak. Selain itu, Negosiasi dan Mediasi cenderung dapat menjaga hubungan baik diantara para pihak sesama pemangku kepentingan (stakeholders) Pupuk Kaltim.

2. Teori Pacta Sunt Servanda menyatakan bahwa perjanjian berlaku sebagai Undang-undang yang bersifat mengikat bagi pihak-pihak yang mengadakan 
perjanjian. Oleh karena itu, perjanjian jual beli saham PT Kaltim Satria Samudera tidak dapat dibatalkan secara sepihak. Cara pembatalan perjanjian yang dapat dilakukan secara hukum yaitu pertama dengan melakukan perjanjian baru yang disepakati para pihak untuk membatalkan perjanjian sebelumnya. Pembatalan tersebut sah secara hukum dan berlaku mengikat bagi para pihak. Akibat hukum dari pembatalan perjanjian tersebut yaitu mengakibatkan perjanjian sebelumnya tidak memiliki dampak dan implikasi hukum apapun dan ketentuan yang mengikat kedua belah pihak mengacu pada perjanjian baru yang disepakati oleh para pihak, termasuk mengenai pembatalan perjanjian jual beli saham PT Kaltim Satria Samudera. Cara kedua yaitu dengan mengajukan pembatalan perjanjian lewat Pengadilan. Dampak hukumnya yaitu perjanjian batal dan keadaan dikembalikan sebagaimana keadaan semula sebelum adanya perjanjian jual beli saham PT Kaltim Satria Samudera.

\section{DAFTAR PUSTAKA}

Buku

Agus Yudha Hernoko, 2011, Hukum Perjanjian Asas Proporsionalitas dalam Kontrak Komersil, Kencana Prenada Media Group, Jakarta.

Ahmadi Miru, 2007, Hukum Kontrak

Perancangan Kontrak, RajaGrafindo

Persada, Jakarta.

I Ketut Artadi dan I Dewa Nyoman Rai Asmara Putra, 2010, Implementasi Ketentuan-ketentuan Hukum

Perjanjian ke dalam Perancangan

Kontrak, Udayana University Press, Denpasar.

Jimmy Joses Sembiring, 2011, Cara

Menyelesaikan Sengketa di Luar

Pengadilan, Visimedia, Jakarta.

Kartini Mulyadi dan Gunawan Wijaya, 2011, Perikatan yang Lahir dari
Perjanjian, RajaGrafindo Persada, Jakarta.

Munir Fuady, 2013, Teori-teori Besar (Grand Theory) dalam Hukum, Kencana, Jakarta.

Rachmadi Usman, 2012, Mediasi di Pengadilan dalam Teori dan Praktik, Sinar Grafika, Jakarta.

Ricardo Simanjuntak, 2011, Hukum Kontrak Teknik Perancangan Kontrak Bisnis, Kontan Publishing, Jakarta.

Salim H.S, 2011, Hukum Kontrak Teori \& Teknik Penyusunan Kontrak, Sinar Grafika, Jakarta.

Salim H.S, 2004, Perkembangan Hukum

Kontrak Innominaat di Indonesia, Sinar Grafika, Jakarta.

Subekti, 2004, Hukum Perjanjian, Intermasa, Jakarta. 
Suyud Margono, 2010, Penyelesaian

Sengketa Bisnis, Ghalia Indonesia, Bogor.

\section{Makalah}

I Nyoman Nurjaya, 2004, Perkembangan Pemikiran Konsep Pluralisme Hukum, makalah untuk dipresentasikan dalam Konferensi Internasional tentang
Penguasaan Tanah dan Kekayaan Alam di Indonesia yang sedang berubah: "Mempertanyakan Kembali Berbagai Jawaban”, Jakarta, 11-13 Oktober 2004.

\section{Peraturan Perundang-undangan}

Undang-undang Republik Indonesia Nomor 40 Tahun 2007 tentang Perseroan Terbatas. 